\title{
A Legal Perspective on Social Media Use and Employment: Lessons for South African Educators
}

\section{P.E.R}

Pioneer in peer-reviewed, open access online law publications

Author

Susan A Coetzee

Affiliation

University of South Africa

Email

coetzsa1@unisa.ac.za

Date Submission

15 November 2018

Date Revised

6 March 2019

Date Accepted

6 March 2019

Date published

19 March 2019

Editor Prof C Rautenbach

How to cite this article

Coetzee SA "A Legal Perspective on Social Media Use and

Employment: Lessons for South African Educators" PER / PELJ 2019(22) - DOI

http://dx.doi.org/10.17159/1727-

3781/2019/v22i0a5778

Copyright

http://dx.doi.org/10.17159/1727-

3781/2019/v22i0a5778

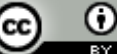

\begin{abstract}
In this article, the author provides a legal perspective on the interplay between social media use and employment. The unique characteristics of social media are identified in order to frame the article before a number of considerations with regard to employment relationships that impact on deciding social media misconduct cases are deliberated upon. Thereafter, the author reflects on the implications of social media transgressions for educators' professions and contemplates the forms that social media misconduct by South African educators can take, with specific focus on defamation. Before the article reaches its conclusion, social media evidence and the impact of the unique characteristics of social media on users' legitimate expectations of privacy are also considered. The article concludes with a few guidelines on how educators can avoid the pitfalls that make social media use potentially hazardous to their employment.
\end{abstract}

\section{Keywords}

Educators; employment; legal perspective; social media. 


\section{Introduction}

Educators may labour under the misconception that their social network sites are personal and private and have nothing to do with their employers. They may feel secure in the protection offered by the divide between work and personal life and in their rights to privacy and freedom of expression. However, instances of unprofessional conduct and misconduct by educators - both of these in connection with their social media use - are on the rise.

Reference is made to a few of the substantial number of American cases involving educators and social media. The first is Munroe $v$ Central Bucks School District, ${ }^{1}$ which deals with an English educator who was dismissed for posting offensive comments about her learners and their parents on her blog. Her blog had only nine subscribers - all of them close friends -and did not include personal information such as her surname, workplace or address. The blog was not password protected, however, and learners succeeded in uncovering her identity. In blog entries posted while she was at work doing score cards she stated that, if she had to be truthful, she would have described the respective learners as a "complete and utter jerk in all ways", a "lazy asshole", a "dunderhead", an "A.I.R.H.E.A.D.", "rat-like", and a "whiny, simpering grade-grubber with an unrealistically high perception of own ability level". She also blogged that the parents of her learners were "breeding a disgusting brood of insolent, unappreciative, selfish brats".

Land v L'Anse Creuse Public School Board of Education ${ }^{2}$ deals with an educator who was fired after photographs, taken in 2005 during a combined bachelor/bachelorette party, surfaced on social media. In the photographs she is shown engaged in a simulated act of fellatio with a male mannequin. She was dismissed for

engaging in lewd behaviour contrary to the moral values of the educational and school community, which undermined her moral authority and professional responsibilities as a role model for students.

* Susanna Abigael Coetzee. BA Ed BEd MEd DEd (University of South Africa) Certificate Programme in Law LLB. Professor, Department of Educational Leadership and Management, University of South Africa. E-mail: coetzsa1@unisa.ac.za. The author wishes to extend her sincere gratitude to Stephan Krüger, Advocate of the High Court of South Africa, and Dr CA Hills for acting as critical readers.

Munroe v Central Bucks School District 090415 FED3, 14-3509 (2015) 3.

Land v. L'Anse Creuse Public School Board of Education 789 NW2d 45820101. 
The State Tenure Commission overturned the court a quo's decision, indicating that dismissal can be justified only by a finding of professional misconduct in instances where the misconduct has directly involved learners. The Michigan Appeal court upheld the commission's decision. A case dealing with unprofessional conduct involving learners is Spanierman $v$ Hughes. It deals with an educator who created a MySpace account to which he invited his learners. The communication on the account was deemed unprofessional because he communicated with his learners in a "peer-like fashion", their banter included sexual innuendos and he posted photos of naked men. The educator voluntarily closed his account but went on to create a new account where he continued his unprofessional conduct. His contract was not renewed and the reason given was the disruptive effect that his mySpace account had had on the learning environment. ${ }^{3}$

In State of Wisconsin $v$ Ebersold, ${ }^{4}$ an educator who sent sexually explicit messages to a learner in an internet chat room was dismissed on the grounds that he had "verbally communicated a harmful description or narrative account to a child, contrary to WIS STAT § 948.11(2)(am) (2005-06)". The educator appealed his conviction, arguing that sending messages via a chatroom does not constitute verbal communication and that the Statute thus does not apply. The court disagreed.

In South Africa an employee who posted a photo of and made statements about a co-employee on Facebook was found guilty of overtly offensive behaviour during the resulting disciplinary hearing. At arbitration the finding was declared substantively and procedurally unfair, but by then the employee had already resigned and her chances of future employment had been negatively affected. ${ }^{5}$ The last case referred to here is that of a lecturer at the University of Cape Town who is under investigation after making a Facebook post that the university described as "grave, unacceptable and disturbing" and as being in conflict with the university's values. According to a news report, the lecturer posted that "the \#MenAreTrash movement is 'bullsh*t' and that women simply cannot attract quality men". The same lecturer posted that, while suffering from depression, he had considered raping and killing his two-year-old daughter. ${ }^{6}$

Spanierman v Hughes 576 F Supp 2d 2922008.

State of Wisconsin v Ebersold 2007 WI APP 232.

MH v Rhodes University (20 March 2017) 20177 BALR 785 (CCMA) paras 35, 40.

Njilo and Chambers 2018 https://www.timeslive.co.za/news/south-africa/2018-08-

15-lecturer-in-facebook-row-faces-urgent-suspension-uct-insists/. 
It is evident that when social media are used indiscriminately, this can have serious employment implications for educators. In this article the author provides a legal perspective on the interplay between social media use and employment. She then draws lessons from this for South African educators on avoiding unprofessional social media conduct and social media misconduct. To frame this article, the unique characteristics of social media are discussed first.

\section{Unique characteristics of social media}

Before looking at the unique characteristics of social media that can make the use thereof hazardous to educators' employment, it is necessary to define "social media". "Social media" are

forms of electronic communication (such as websites for social networking and microblogging) through which users create online communities to share information, ideas, personal messages, and other content (such as videos). ${ }^{7}$

Social media sites and applications include Facebook, WhatsApp, Twitter, MySpace, LinkedIn, YouTube and Instagram. ${ }^{8}$ In this article Facebook is used as the primary example.

The first characteristic of social media that can make them hazardous to educators' employment are their so-called interactive, network or grapevine nature and their disposition to have a fluid, unidentifiable audience. ${ }^{9}$ Static text is turned into dialogue and posts shared with friends on social media may well, through re-sharing and tagging, end up being read and commented on by an unknown number of people unfamiliar with the original sharer. ${ }^{10}$ For example, two Facebook users who have a mutual friend, but who are not friends with each other, may gain access to posts made by each other when the mutual friend comments on a post made by either of them. ${ }^{11}$ This was the case in Hanniker / One and Only Cape Town where the applicant made an offensive comment in response to a Facebook post by a colleague and where one of that colleague's Facebook friends saw the comment and reported it. The applicant denied making the posts and

\footnotetext{
7 Merriam-Webster.com date unknown https://www.merriam-webster.com/ dictionary/social\%20media.

8 Beaver et al 2013 https://www.americanbar.org/content/dam/aba/adminis trative/litigation/materials/aba-annual-2013/written_materials/15_1_social_media_ evidence.authcheckdam.pdf; Boyd and Ellison 2008 JCMC 212.

$9 \quad$ Burkell et al 2014 Inf Commun Soc 975; Cain 2008 Am J Pharm Educ 2; Douglas 2015 MALR 367.

$10 \quad$ Lam 2016 Employee Relations 420, 433.

11 Sedick v Krisray (Pty) Ltd 20118 BALR 879 (CCMA) para 20.
} 
argued that she had restricted access to her Facebook page and that her Facebook page must thus have been hacked. The commissioner brought it to her attention that since she had made the post on another person's Facebook page, she had had no control over who would have access to it. ${ }^{12}$

An employee was dismissed in National Union of Food, Beverage, Wine, Spirits and Allied Workers Union obo Arendse / Consumer Brands Business Worcester for gross misconduct because he had brought the company's name into disrepute by posting "false, derogatory, defamatory and racial statements/remarks about the company and its management" on his Facebook page. ${ }^{13}$ In this case the supervisor gained access to these posts via the Facebook of a colleague who was a Facebook friend of the employee and the commissioner accepted this as a legitimate means of coming into possession of the publication. ${ }^{14}$ In US $v$ Mereglido the court held that the defendant had lost his legitimate expectation of privacy when he disseminated his message to his Facebook friends. It was thus not a Fourth Amendment violation to gain access to the defendant's Facebook profile through one of these friends. ${ }^{15}$ This characteristic makes it almost impossible to destroy Facebook evidence. In Pritchard $v$ Van Nes the defendant deleted her Facebook posts but the evidence could be obtained from the Facebook pages of her friends who commented on her posts. ${ }^{16}$

The second characteristic is that social media create a false sense of camaraderie and familiarity. Social media users tend to regard their social media friends in the same light as they do friends in the traditional sense, that is, as members of a close-knit group of people. ${ }^{17}$ This characteristic makes users susceptible to being "catfished". The term refers to the creation of fake social networking profiles with the purpose of befriending someone, but with deceitful intentions. ${ }^{18}$ In National Union of Food, Beverage, Wine, Spirits and Allied Workers Union obo Arendse / Consumer Brands Business Worcester the employee was catfished when the company opened a fake

Hanniker / One and Only Cape Town (Pty) Ltd 201711 BALR 1191 (CCMA) paras 12, 18 (hereafter Hanniker / One).

13 National Union of Food, Beverage, Wine, Spirits and Allied Workers Union obo Arendse / Consumer Brands Business Worcester, a Division of Pioneer Foods (Pty) Ltd 20147 BALR 716 (CCMA) para 3 (hereafter National Union of Food, Beverage, Wine, Spirits and Allied Workers Union obo Arendse).

14 National Union of Food, Beverage, Wine, Spirits and Allied Workers Union obo Arendse paras 3, 10, 16. US v Mereglido 2012 WL 3264501 SDNY Aug 10, 2012 para 2 (hereafter US $v$ Mereglido).

16 Pritchard v Van Nes 2016 BCSC 68663 para 31-31 (hereafter Pritchard v Van Nes).

17 Amedie $2015 \mathrm{http}: / /$ scholarcommons.scu.edu/engl_176/2 4, 9.

18 Amedie $2015 \mathrm{http}: / /$ scholarcommons.scu.edu/engl_176/2 10. 
account and sent the employee a friend request. The commissioner indicated that by readily accepting the invitation of a stranger the employee had made his posts public himself. ${ }^{19}$

The third characteristic of social media is the limited control that it allows users over their online identities. This sense of "über-connectivity" gives employees a false sense of attachment, control and empowerment. ${ }^{20}$ Finding an audience tends to strengthen deindividuation, that is, losing oneself in the group, finding strength in the group, and forming a "toxic disinhibition". ${ }^{21}$ Because social media act as echo chambers in which people can find confirmation of their views, users feel safe to use them to spread hate or false rumours, or to solicit support. ${ }^{22}$ Lam $^{23}$ warns that, what an employee regards as voicing an opinion or complaint about work, the employer may regard as a threat to the reputation of the business.

The fourth characteristic is the limited control that social media allow users over their online identities. By creating a profile, one inadvertently shares personal information. Not only is a person's online identity created by the person's profile, but also by the digital footprint created by the information posted, "liked" or "shared", the groups the person associates with, and the persons he or she befriends. Even the comments other users leave on a person's Facebook site and the photos a person is tagged in become "testimonials" to a person's online identity. ${ }^{24}$ It should be kept in mind that social media networks generate revenue through exposure, especially by allowing marketing companies to use information not protected by privacy settings. It is thus unlikely that networks will have social media users' best interests in mind when the disclosure of personal information is at stake, because a lack of privacy settings means higher rates of exposure and higher revenue. ${ }^{25}$

The fact that social media sites are public spaces which lack information security and confidentiality is the fifth characteristic that can make social media use hazardous to educators' employment. DeNardis ${ }^{26}$ describes this

19 National Union of Food, Beverage, Wine, Spirits and Allied Workers Union obo Arendse para 9.

$20 \quad$ Ghoshray 2013 N Ky L Rev 616-617; Lam 2016 Employee Relations 433.

21 Thomas 2018 https://www.thenational.ae/opinion/comment/there-s-strength-ofhate-in-numbers-on-social-media-1.763908.

22 Thomas 2018 https://www.thenational.ae/opinion/comment/there-s-strength-ofhate-in-numbers-on-social-media-1.763908.

23 Lam 2016 Employee Relations 433.

24 Grimmelmann 2008-2009 lowa L Rev 1153, 1174.

25 Spinelli 2010 Elon Journal of Undergraduate Research in Communication 59, 67.

26 DeNardis "Social Media Challenge to Internet Governance" 349. 
as the "disconnect between perceptions of online anonymity and the technically embedded identity infrastructures". Even where a person creates a Twitter account or blog using a pseudonym, the identity infrastructures embedded in the technology will allow law enforcement to obtain identity information from the service provider. ${ }^{27}$ Beaver et al refer to the fact that several American courts have held that defendants have no proprietary interest or expectation of privacy with regard to their tweets, because Twitter's terms of service contain a statement that a Twitter user provides Twitter with a licence to distribute to anyone at any time whatever the user tweets. ${ }^{28} \mathrm{~A}$ warning that the personal information that users upload "may become publicly available" is also included in the Facebook principles. Principle 2, Ownership and Control of Information, contains a warning that privacy cannot be guaranteed:

People should have the freedom to decide with whom they will share their information, and to set privacy controls to protect those choices. Those controls, however, are not capable of limiting how those who have received information may use it, particularly outside the Facebook Service. ${ }^{29}$

Beaver et al and Spinelli warn that one should regularly check preferred settings because those may have changed as a result of updates. The default setting for new and updated features may be "public view". ${ }^{30}$

The last characteristic is the fact that social media posts are imminent in the sense that they are "out there" instantaneously and they can draw immediate responses. ${ }^{31}$

\section{Employment relationship considerations in social media transgressions}

Employees are regarded as representing their employers who thus have a legitimate interest in protecting the image of the business. ${ }^{32}$ Because inappropriate posts can be associated with the name of the business, the employer may face a backlash from customers, prospective customers and

27 DeNardis "Social Media Challenge to Internet Governance" 351.

28 Beaver et al 2013 https://www.americanbar.org/content/dam/aba/ administrative/litigation/materials/aba-annual-2013/written_materials/15_1_social media_evidence.authcheckdam.pdf 8.

$29 \quad \bar{F}$ acebook 2018 https://www.facebook.com/principles.php.

30 Beaver et al 2013 https://www.americanbar.org/content/dam/aba/ administrative/litigation/materials/aba-annual-2013/written_materials/15_1_social media_evidence.authcheckdam.pdf 4; Spinelli 2010 Elon Journal of Undergraduate Research in Communication 62.

31 Homann Legal Implications of Defamatory Statements 18. 
other stakeholders as a result of an inappropriate post. ${ }^{33} \mathrm{~A}$ case in point is Media Workers Association of SA on behalf of Mvemve and Kathorus Community Radio dealing with an employee's dismissal for tarnishing the image of Kathorus Community Radio's Board. The employee concerned was given a written warning subject to his issuing written apologies and posting an apology on Facebook for criticising the Board and calling the station manager a criminal. He failed to comply. ${ }^{34}$ Davey ${ }^{35}$ argues that, because of the potential wide audience, the propensity for "brand damage" is particularly high in the case of social media misconduct. In fact, Mangan ${ }^{36}$ states that the concept of "business reputation" is at the core of United Kingdom employment rulings involving employees' social media use. As discussed below, educators' social media transgressions will not only affect the employer but will also affect the reputation of the school and profession.

The second consideration is the fact that employment relationships are based on the utmost good faith. ${ }^{37}$ Common law compels employees to act in the best interests of the employer and to behave honestly. ${ }^{38}$ Employees who criticise or make derogatory remarks about their employer, institution or profession on social media open themselves up to disciplinary proceedings. ${ }^{39}$ Behaviour that destroys trust and hampers proper performance and/or contractual obligations could make a continued employment relationship intolerable and provide grounds for dismissal. ${ }^{40} \mathrm{It}$ will be regarded as aggravating circumstances if an employee is dishonest and lies, for example about the privacy settings of his or her Facebook account. ${ }^{41}$ In such an instance, even though the item posted on social media may not have been of a serious nature, the employer can defend dismissal

Shange 2016 http://www.news24.com/SouthAfrica/News/yes-your-boss-can-fireyou-for-social-media-posts-attorney-20160202; Subramanien and Whitear-Nel 2013 SAJLR 11.

Media Workers Association of SA obo Mvemve and Kathorus Community Radio 201031 ILJ 2217 (CCMA) para 5.7.

Davey 2016_https://www.golegal.co.za/off-duty-misconduct-in-the-age-of-socialmedia/.

Mangan "Social Media in the Workplace" 210.

Alfreds 2015 https://www.fin24.com/Tech/News/Privacy-is-dead-on-social-medialegal-expert-20151016.

Jolly, Ellison and Wong 2014 Governance Directions 170.

See, for example Fredericks / Jo Barkett Fashions 2011 JOL 27923 (CCMA); National Union of Food, Beverage, Wine, Spirits and Allied Workers Union obo Arendse; Sedick $v$ Krisray.

Thornthwaite 2016 Asia Pac J Hum Resour 340.

See for example Griffiths $v$ Rose 2011 FCA 30 paras 10, 52 (hereafter Griffiths v Rose); Hanniker / One paras 12, 18. 
by arguing that the dishonesty has made the employment relationship intolerable. ${ }^{42}$

The third consideration is the common law burden placed on employers by their liability for the delicts of their employees. ${ }^{43}$ If discrimination, hate speech, harassment, violation of privacy or defamation via social media occurred "during the course and scope of employment", the employer can be held vicariously liable. ${ }^{44}$ Employers can be held vicariously liable even in instances where the wrongful conduct took place outside the workplace if "objectively there is a sufficiently close link between the employee's act and the purposes and business of the employer". ${ }^{45}$

The heads of the provincial departments of basic education are the employers of public school educators appointed in the so-called subsidised posts. ${ }^{46}$ This means the state can be held vicariously liable for the wrongful conduct of these educators, not only in terms of common law, but also in terms of section 60(1)(a) of the South African Schools Act 84 of 1996. This section provides for statutory state vicarious liability with regard to public schools and stipulates that the state can be held vicariously liable for

any delictual or contractual damage or loss caused as a result of any act or omission in connection with any school activity conducted by a public school.

State vicarious liability also applies with regard to educators appointed in terms of section 20(4) of the Schools Act who are in the employ of the school. ${ }^{47}$ It will not apply in relation to wrongful conduct which is not within the scope of employment or related to school activities. However, common law vicarious liability (as extended by the Constitutional Court) may apply in such instances. ${ }^{48}$ There is also the argument that should the social media misconduct include, on the part of the department or school as organs of

42 Item 3.4 of the Code of Good Practice: Dismissal Schedule 8 to the Labour Relations Act 66 of 1995.

43 Van Vuuren 2015 https:/www.werksmans.com/wp-content/uploads/2015/ 11/044191-WERKSMANS-legal-nov-legal-impacts.pdf.

44 Subramanien and Whitear-Nel 2013 SAJLR 12.

$45 \quad$ Pehlani v Minister of Police 2014 ZAWCHC 146 (25 September 2014) para 23.

$46 \quad$ Section 1 of the Employment of Educators Act 76 of 1998.

47 EC for Education and Culture, Free State v Louw 2005 ZASCA 85 (23 September 2005) paras 12-13.

48 Coetzee 2018 CARSA 32. See $K v$ Minister of Safety and Security 2005 ZACC 8 (13 June 2005) paras 44-45; and Fv Minister of Safety and Security 2011 ZACC 37 (15 December 2011) paras 49-50. 
state, a failure in their constitutional duty to "respect, protect, promote and fulfil the rights in the Bill of Rights", they can be held directly liable. ${ }^{49}$

The Protection of Personal Information Act 4 of 2013 also creates civil statutory vicarious liability for the invasion of privacy. ${ }^{50}$ This Act gives expression to the right expressed in section 14(d) of the Constitution not to have the privacy of one's communications infringed upon. ${ }^{51}$ It includes protection of the "informational privacy right", which comprises protection against "the unlawful collection, retention, dissemination, and use of personal information". ${ }^{52}$ Scholars such as Gondwe, and Millard and Bascerano, ${ }^{53}$ argue that employers should be regarded as "responsible parties" in terms of section 1 of this Act because employers determine the purpose of and means for the processing of the personal information of data subjects. As "responsible parties" employers can be held accountable for their employees' unlawful processing of personal information. Millard and Bascerano ${ }^{54}$ contend that section 9(2) of this Act limits defences that employers can bring against statutory vicarious liability for delicts committed by their employees. They state that neither "good deeds", "pro-activeness" nor "wrongful conduct not occurring while the employee was at work" will suffice as a defence.

The last consideration is that employees' conduct may not negatively impact on employers' legitimate business interests. ${ }^{55}$ Employers may be justified in limiting employees' right to freedom of expression when using the work's equipment. The use of the employer's computer after hours, irrespective of where this is done, is still regulated by the employer's policies. The defence of the applicant that certain WhatsApp conversations took place outside working hours and while he was off the work premises was rejected in Masemola $v$ Commission for Conciliation, Mediation and Arbitration. Pienaar AJ held that the employer owes a duty to protect employees as well as others who have dealings with the employer against sexual harassment by his or her employees even outside the workplace and working hours (subject

\footnotetext{
49 See Coetzee 2018 CARSA 30-44.

50 Millard and Bascerano 2016 PELJ http://dx.doi.org/10.17159/17273781/2016/v19i0a5553, 24, 31.

51 Section 14(d) of the Constitution of the Republic of South Africa, 1996 (hereinafter the Constitution); Preamble of the Protection of Personal Information Act 4 of 2013.

52 Roos 2012 SALJ 395; Mistry v Interim National Medical and Dental Council 1998 ZACC 10 (29 May 1998) para 23.

$53 \quad$ Gondwe Protection of Privacy in the Workplace 273; Millard and Bascerano 2016 PELJ http://dx.doi.org/10.17159/1727-3781/2016/v19i0a555 1.

54 Millard and Bascerano 2016 PELJ http://dx.doi.org/10.17159/17273781/2016/v19i0a555 4.

55 Thornthwaite 2016 Asia Pac J Hum Resour 333, 349.
} 
to the within the scope of employment test). The commissioner concluded that the conversations clearly constituted sexual harassment and impacted on the relevant parties' work relationship. ${ }^{56}$ In an Australian case, Griffiths $v$ Rose, the employee watched pornography on the employer's computer after hours using his own internet connection. In this case the court emphasised that since the employer used the company's computer, the company, as the owner, could prescribe how it might be used. ${ }^{57}$

Employers' legitimate business interests also give them a legitimate right to extract productivity from their employees and to protect resources. ${ }^{58}$ The excessive use of social media during working hours (for non-employment purposes) could constitute misconduct because it hampers employees' productivity and affects infrastructure costs negatively. ${ }^{59}$ Social media use can attract spam. Spam can entice employees to stay online longer at the expense of the employer with a loss of productivity and the possibility that it could slow the network down, resulting in clogging, or even cause a network crash. ${ }^{60} \mathrm{~A}$ further business interest is found in the security risks such as viruses that internet-use holds and which could result in the loss of confidential information. ${ }^{61}$ Due to the nature of social media, by posting information about work an employee runs the risk of inadvertently disclosing sensitive or confidential information which could be very damaging to the employer. ${ }^{62}$

\section{Educator professionalism and social media-related unprofessional conduct}

Educators represent their employer as well as the schools at which they work and the profession. The National School Public Relations Association of the United States of America maintains that what anybody involved with a school says or does "create[s] the images and forge[s] the relationships that build the reputation" of the school. Educators' actions and words in particular play a major role in building and protecting a school's reputation. ${ }^{63}$

56 Masemola $v$ Commission for Conciliation, Mediation and Arbitration 2016 ZALCJHB 183 (17 May 2016) paras 14-17.

$57 \quad$ Griffiths $v$ Rose para 24.

58 Subramanien and Whitear-Nel 2013 SAJLR 10.

59 Du Toit 2018 https://labourguide.co.za/most-recent/1358-social-media-guidelineson-the-policy-for-employees-using-social-media-for-non-business-purposes; Toker Bros (Pty) Ltd and Keyser 200526 ILJ 1366 (CCMA) para 1.

$60 \quad$ McGregor 2004 SA Merc LJ 644, 647, 649.

61 Gondwe Protection of Privacy in the Workplace 261.

62 Miller 2013 FDCC Quarterly 285.

63 National School Public Relations Association date unknown https://www.nspra.org/cap. 
In the light of the Supreme Court of Appeal's decision in Media 24 v SA Taxi Securitisation, a school's public image (its reputation) is worthy of protection and forms part of its patrimony. Compensation can be claimed for damage done to the school's reputation under the action legis Aquiliae. ${ }^{64}$ In Flocutt $\checkmark$ Eisenberg ${ }^{65}$ Murray AJ stated that

[i]t is trite that not only private individuals, but also legal persona ... have a right to their good name and unimpaired reputation and that the dignitas of companies can also be infringed.

The consequences for educators of their inappropriate use of social media are complex, due to the standard of professionalism educators are held to. ${ }^{66}$ During the first phase of their two-phase-study amongst first-year teacher education students at an American university, conducted before the participants were put through a process of professionalisation, Kimmons and Veletsianos ${ }^{67}$ found that most of the participants did not appreciate the impact that their current social media conduct could have on their future professional identities. At that stage the participants regarded only content related to illegal actions such as underage drinking and drug use as unprofessional content to be avoided when using social media. Kimmons and Veletsianos ${ }^{68}$ concluded

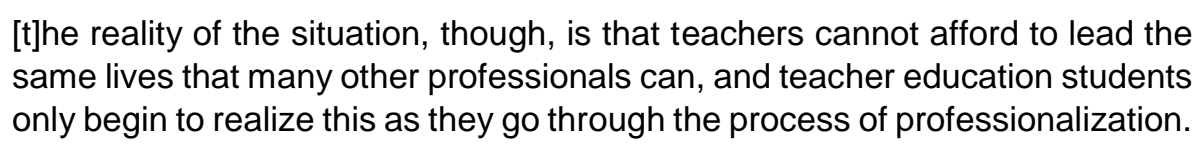

Thus, by the time educators enter the profession they have already created online personae that may pose a danger to their professional reputations. ${ }^{69}$ After the professionalisation process, participants in the study conducted by Kimmons and Veletsianos ${ }^{70}$ described being subjected to a high professional standard as a necessary sacrifice because educators work with and are role models to children. Also Akiti, and Beckmann and Füssel, ${ }^{71}$ observe that educators' professionalism and the expectations in relation to the fact that they work with children and are role models to children are

$64 \quad$ Media 24 v SA Taxi Securitisation 2011 ZASCA 117 (5 July 2011) paras 43, 49, 6465. Flocutt (Pty) Ltd v Eisenberg 2016 ZAFSHC 200 (20 October 2016) para 6 (hereafter Flocutt).

66 Akiti 2012 Val U L Rev 130-131; Bagley, Hargraves and DiGiacinto 2014 Radiologic Technology 380, 389.

$67 \quad$ Kimmons and Veletsianos 2015 Learn Media Technol 498.

68 Kimmons and Veletsianos 2015 Learn Media Technol 498.

69 Cain 2008 Am J Pharm Educ 6.

$70 \quad$ Kimmons and Veletsianos 2015 Learn Media Technol 488, 494.

71 Akiti 2012 Val U L Rev 130-131; Beckmann and Füssel 2013 De Jure 559. 
central to any consideration of the role of educators. Page ${ }^{72}$ concluded after studying 300 disciplinary orders against teachers from the General Teaching Council (GTC) for England that teacher professionalism extends to life outside the school and that teachers are held professionally accountable for their conduct inside and outside school. Akiti supports this view, ${ }^{73}$ referring to several American court cases.

It is trite that in terms of the principle imperitia culpae adnumeratur that a unique expertise or professionalism will impact on the standard of reasonableness expected of persons exercising that skill or members of a particular profession. ${ }^{74}$ Thus when determining whether an educator has committed a delict, the standard of reasonableness used will be that of a professional educator working with children and being a role model to those children.

South African educators' use of social media must be within the bounds of the SACE Code of Professional Ethics. Failure to adhere to it could result in an educator's being found in breach of this Code and deregistered. ${ }^{75}$ Educators have the obligation to create, observe and keep intact professional boundaries so that they do not abuse the position of power which they acquire as a result of their professional status. They must regard teaching as a "noble calling", "act in accordance with the ideals of their profession" and not "bring the teaching profession into disrepute". ${ }^{76}$ In addition to this general ethical principle, which will most probably always come into play in social media misconduct cases, several other ethical principles contained in the SACE Code of professional ethics can also be breached by inappropriate social media use. These include

- refraining from undermining the status and authority of colleagues, for example by not posting derogatory remarks about the department, principal or a school management team member;

Page 2013 British Education Research Journal 560.

Akiti 2012 Val U L Rev 131, fn 47.

Neethling and Potgieter Law of Delict 147.

Sections 21-23 of the South African Council for Educators Act 31 of 2000.

SACE 2001 https://www.sace.org.za/assets/documents/uploads/sace_24644-201702-08-

Code\%20of\%20ethics\%20Brochure\%20FINAL\%20PRINT\%205\%20SEPT.pdf paras 2.1, 2.4, 2.5. 
- using proper procedures to address issues of professional incompetence or misbehaviour, for example by not making public disclosures about such issues on social media;

- promoting a harmonious relationship with parents, for example by not posting offensive comments about parents;

- using appropriate language and behaviour when interacting with colleagues, for example by not posting racist or sexist comments;

- avoiding humiliating or abusing colleagues or learners, for example by not using social media to sexually harass colleagues or to groom learners;

- serving the employer to the best of the educator's ability, for example by not using social media for non-work related activities during working hours; and

- refraining from discussing confidential and official matters with unauthorised persons, for example by not discussing learners' disciplinary matters, performance or HIV/AIDS status or the school's financial matters on social media sites. ${ }^{77}$

Unprofessional conduct will in most cases also constitute misconduct and, in some cases even a civil or criminal offence. It should be kept in mind that the unprofessional conduct will be dealt with by SACE and the misconduct by the employer. ${ }^{78}$

\section{Educator social media misconduct}

Social media misconduct by public school educators is regulated by the Employment of Educators Act 76 of 1998 and in particular Schedule 2, which contains the Disciplinary Code and Procedures for Educators. Schedule 2 should be read with Schedule 8 (Code of Good Practice Dismissal) of the Labour Relations Act 66 of $1995 .{ }^{79}$ When dealing with social media misconduct which cannot be classified as serious misconduct, the employer

SACE 2001 https://www.sace.org.za/assets/documents/uploads/sace_24644-201702-08-Code\%20of\%20ethics\%20Brochure\%20FINAL\%20PRINT\%205\%20SEPT .pdf paras 3.5, 4.1,6.1, 6.3, 6.6, 8.2, 8.3.

78 Coetzee 2011 CARSA 52.

79 Schedule 2, s 3(1) of the Employment of Educators Act 76 of 1998. 
will determine the seriousness of the misconduct by considering the following factors:

(a) The extent to which the misconduct impacts on the work of the Department of Basic Education or provincial department of (basic) education, or the public school, ...

(b) The nature of the educator's work and responsibilities; and

(c) The circumstances in which the alleged misconduct took place ${ }^{80}$

Social media defamation may constitute misconduct in the form of unfair discrimination, where the defaming words unfairly discriminate on any of the grounds listed in section 9 of the Constitution and section 18(1)(k) of the Employment of Educators Act 76 of 1998 or analogous grounds. ${ }^{81}$ The use of social media may also constitute misconduct if an educator:

- "without permission wrongfully ... uses the property of the State, a school...";

- "while on duty, conducts himself or herself in an improper, disgraceful or unacceptable manner";

- "displays disrespect towards others in the workplace or demonstrates abusive or insolent behaviour";

- "intimidates or victimises fellow employees, learners or students";

- "commits a common law offence". ${ }^{82}$ Common law offences will include violations of personality interests such as a person's good name or reputation (defamation), dignity (insult) and privacy (disclosure of private facts).

\subsection{Defamation as social media misconduct}

Unprofessional conduct will in most cases also constitute misconduct and in some cases even a civil or criminal offence. Neethling ${ }^{83}$ emphasises that, because Facebook is in the public domain, posting private information about others will constitute a prima facie violation of privacy. If the post is also inappropriate and offensive, the post will be prima facie wrongful. If the post

Schedule 2, s 3(3) of the Employment of Educators Act 76 of 1998.

Section 9 of the Constitution.

Sections 18(1)(c), 18(1)(q), 18(1)(t), 18(1)(u), 18(1)(dd) of the Employment of Educators Act 76 of 1998.

83

Neethling 2014 LitNet Akademies 40. 
cannot be justified, the actio iniuriarum could be used to claim satisfaction for the injury caused by way of damages. ${ }^{84}$

Due to the nature of social media, a presumption of publication is created as soon as a comment is posted on the internet. ${ }^{85}$ It is highly unlikely that this presumption will be rebutted, because publication is probable. ${ }^{86}$ Once the defendant has established that a defamatory statement was published and the defendant was responsible for the publication, a further presumption is created that the statement was unlawful and intentional. The publisher of the statement must then rebut the presumption by proving that the statement is true and in the public interest or benefit, or constitutes fair comment. ${ }^{87}$ With regard to the defence of truth and of being in the public interest, Willis $\mathrm{J}$ emphasises in $H v W^{88}$

In our law, it is not good enough, as a defence to or ground of justification for a defamation, that the published words may be true: it must also be to the public benefit or in the public interest that they be published. A distinction must always be kept between what 'is interesting to the public' as opposed to 'what it is in the public interest to make known'.

It may be wise to note that how the inappropriate comments are phrased will affect whether they are regarded as fair comment or not. In Flocutt $v$ Eisenberg Murray AJ refers to the fact that the respondent's defamatory warnings phrased as "purported factual statements" do not invite other persons to form a subjective perception about them and are based on unsupported allegations of other persons and can thus not be regarded as fair comment. 89 Liability for defamation can arise even from innuendos. Saunders $\mathrm{J}$ confirmed in Pritchard $v$ Van Nes ${ }^{90}$ that, if a reasonable reader would draw a defamatory innuendo from the words, liability will arise.

Educators' employment may also be affected if they respond positively to an inappropriate post. Neethling and Potgieter ${ }^{91}$ emphasise that

not only the person with whom the defamatory remarks originated, but also any person who repeats, confirms, or even directs attention to them, will in principle be responsible for the publication.

\footnotetext{
$84 \quad$ Neethling 2014 LitNet Akademies 40.

$85 \quad$ Nel 1997 CILSA 167.

$86 \quad$ Neethling, Potgieter and Visser Neethling's Law of Personality 133.

$87 \quad K$ Khumalo v Holomisa 2002 ZACC 12 (14 June 2002) para 18; Maharaj 2015 De Rebus 28; Neethling and Potgieter Law of Delict 357; Nel 1997 CILSA 167.

$88 \quad H v W 2013$ ZAGPJHC 1 (30 January 2013) para 27 (hereafter $H v W$ ).

$89 \quad$ Flocutt para 43.

$90 \quad$ Pritchard $v$ Van Nes para 66.

$91 \quad$ Flocutt para 9; Neethling and Potgieter Law of Delict 354.
} 
There are many points of production or possible creators. ${ }^{92}$ Davey states that everyone in the chain of publication and who has contributed to the publication of the defamatory statement is liable. ${ }^{93}$

One can be held liable for third-party defamatory comments on one's social media site. In Pritchard $v$ Van Nes the Supreme Court of British Columbia considered liability for third-party defamatory comments which hinted at the fact that a specific music teacher was a paedophile. Saunders $J$ identified three modes of defamation present in that case: the defendant's own defamatory innuendos posted on her Facebook page, the republication of these remarks by others, and then the defamatory remarks made in response to the defendant's posts. ${ }^{94}$ The judge applied the three exceptions (as identified by Brown in The Law of Defamation in Canada 1994) to the rule that a person can be liable for his or her own defamatory publications only. Where the information republished is the same or substantially the same as the original, a person can be held liable for third party defamatory comments if (1) the defendant intended or has authorised others to publish defamatory comments on his or her behalf, (2) the defendant published the defamatory comments to a person who is under a moral, legal or social duty to repeat the comments to another person and (3) the responsive remarks were the natural and probable result of his or her publication. ${ }^{95}$

The principle that a non-creator of offensive posts can be held liable was confirmed in Dutch Reformed Church Vergesig vs Rayan Sooknunan. ${ }^{96}$ This case deals with an application by the Church for an order interdicting Sooknunan/GDWM from publishing certain harmful allegations and comments. Sooknunan (or GDWM) was found to be the creator of the Facebook page and to have allowed harmful comments to be posted on it. The reasoning behind the principle that a person can be held liable for what a third party has posted on his or her social media sites is that if one creates the opportunity (space) for unlawful content to be published, one will be regarded as the publisher and will be held responsible for the content of that space/pages. ${ }^{97}$ This is especially important for those who create blogs or discussion forums. In Isparta $v$ Richter, the second defendant did not post any comments but was tagged in the first defendant's posts. Hiemstra J held

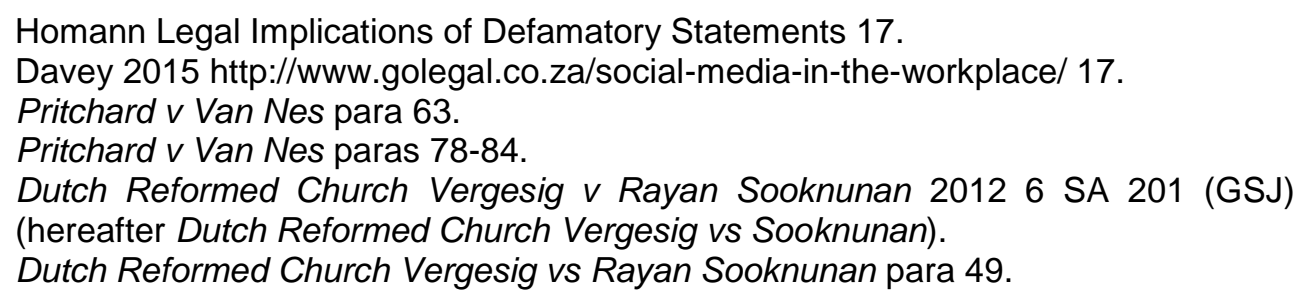


that the second defendant was as liable as the first defendant because, though not the author of the postings, he knew about them and allowed his name to be associated with that of the first defendant. ${ }^{98}$

Even where an employee does not identify his or her employer by name, he or she can still be found to have damaged the employer's reputation. In Sedick $v$ Krisray ${ }^{99}$ the commissioner held that though the employer was not identified, the parties to the communication included former and current employees and this made the employer identifiable. It was held in Isparta $v$ Richter ${ }^{100}$ that

[i]f a plaintiff is not directly referred to in the defamatory statement, the plaintiff must plead the circumstances which would have identified him or her to the addressees.

The 2-question-test to determine whether defamatory material refers to the plaintiff where the plaintiff is not directly named was set out by Viscount Simon LC in Knupffer $v$ London Express Newspapers. ${ }^{101}$ This test was consolidated into a one-question-test, that is, whether the defamatory words can be "understood to be published of and concerning the plaintiff". ${ }^{102}$ One aspect that will render the employer identifiable is when the employer or place of employment are identified on the employee's social media profile. If an employee has identified either his or her employer or place of employment on his or her social media profile, and especially if access to the site is not restricted, it will be almost impossible to rely on the fact that the employer or place of work was not mentioned in the defamatory post. ${ }^{103}$ If an employee has co-employees as social media friends, enough information may exist, even though not mentioned on the social media site, that may make the institution, department or co-employee recognisable to these friends. ${ }^{104}$

Douglas ${ }^{105}$ argues that, because of the sharing function, defamation by social media has the potential to be more damaging than other comparable defamatory matter and could equally draw higher awards of damages. This

98 $\checkmark$ Richter).

100

101

102

103

104

105 810C.

Isparta v Richter 2013 ZAGPPHC 243 (4 September 2013) para 35 (hereafter Isparta

Sedick $v$ Krisray para 53.

Isparta $v$ Richter para 20.

Knupffer $v$ London Express Newspapers 1944 UKHL 1 para 3.

South Africa Associated Newspapers Ltd v Estate Pelser 19754 SA 797 (A) para

Karlen 2014 Allied Academies International Internet Conference 56.

Bagley, Hargraves and DiGiacinto 2014 Radiologic Technology 380.

Douglas 2015_MALR 371. 
is because the inappropriate post can be seen by more people and be shared out of context.

Failing to comply with an order to remove offending posts may result in a court order to submit the digital devices so that a sheriff of the court can remove them. In $K S \vee A M^{106}$ Molahlehi J ordered the respondent to hand the digital devices under his control to the Sheriff of the Court for temporary custody so that a forensic expert could identify and permanently remove any photograph, video, audio and or records relating to the applicant. Where the offender is in control of private material in relation to the victim (such as naked photos), continuous violations of the victim's rights to dignity, privacy, bodily and psychological integrity are possible as long as the offender retains such control. Constitutional imperatives call for protecting the victim against future rights violations. As was held in National Director of Public Prosecutions $v$ Mahomed ${ }^{107}$ the right to privacy is violated also by dispossessing a person of material that he or she is entitled to hold in private. The violation occurs when and for as long as the dispossession of control over the private material continues.

\section{Social media evidence}

Social media evidence can be the basis of the transgression itself, for example defamatory comments posted on Facebook, or it can be evidence of a transgression that was not committed via social media. ${ }^{108}$ There are ample examples of the latter. Co-employees made copies of an employee's Facebook posts including photographs of her on the beach and messages about the lovely time she was having in Chatfield $v$ Deputy Head (Correctional Service Canada). The posts evidenced that the employee was on holiday instead of on the bereavement leave for which she had applied. ${ }^{109}$ Another example is the case of Zungu / Department of Education - KwaZuluNatal, in which posts from a learner's Facebook page were used as evidence to indicate a relationship between the educator and the learner. ${ }^{110}$

Social media symbols such as the "thumbs up-sign" and emoticons are used as evidence. Malusi AJ held in_Beautiful You Health and Beauty Clinic $\checkmark$ Moolman, a case dealing with restraint of trade, that "likes" can be taken

\footnotetext{
$106 \quad K S$ v AM 2017 ZAGPJHC 297 (24 October 2017) paras 39, 53, 65.

$107 \quad$ NDPP $\vee$ Mahomed 2007 ZASCA 135 (8 November 2007) paras 18.

108 Thornthwaite 2016 Asia Pac J Hum Resour 333.

109 Chatfield. Deputy Head (Correctional Service Canada) 2017 PSLREB 2 paras 1819.

110 ELRC 2018 http://www.elrc.org.za/awards/case-no-pses434-1617-kzn-0.
} 
as evidence of a relationship between the respondent and her previous employer's customers. ${ }^{111}$ In the American case, Bland $v$ Roberts, ${ }^{112}$ the Fourth Circuit Court of Appeals concluded that the "thumbs up" symbol constitutes "symbolic expression" through which a person makes a "substantive statement". As such it constitutes "pure speech", which is protected under the right to freedom of speech. Griessel ${ }^{113}$ states that emoji's can be used to prove facts relating to a particular communication or in certain contexts can be indicative of harassment (including sexual harassment), ridicule or unfair discrimination. Because the interpretation of an emoticon can be ambiguous, interpretation within context is required. This was done in Gus Ghanam v John Does where the court considered the emoticon together with the manner in which comments were made and the far-fetched suggestions included in the posts to indicate "intent to ridicule, criticize, and denigrate". 114

As a matter of fact, all social media evidence will be considered in context. A single post may not be offensive, but when considered in context and together with other posts, it may be. In South African Human Rights Commission obo South African Jewish Board of Deputies v Masuku, for example, the Equality Court held that after viewing posts with due consideration to all the relevant circumstances, the statements at issue undoubtedly amounted to hate speech. ${ }^{115}$ Willis $\mathrm{J}$ concluded in $H v W$ that the background of postings, together with the words themselves, gave evidence of the defendant's malicious intent when posting the offending comments and thus defeated her defence of fair comment. ${ }^{116}$ This approach was followed in the arbitration case between NAPTOSA obo Makhaphela Khayalethu Stephen / South West Gauteng TVET College and Department of Higher Education and Training where the arbitrator held that the WhatsApp messages concerned, considered within context, indicated that the respondent's interpretation was more probable. ${ }^{117}$ The arbiter held that such messages can be classified as sexual harassment since the definition

\footnotetext{
111 Beautiful You Health and Beauty Clinic (Pty) Ltd $v$ Moolman 2015 ZAECPEHC 13 (10 March 2015) para 17.

$112 \quad$ Bland v Roberts 730 F3d 368 4th Cir 2013 para 386.

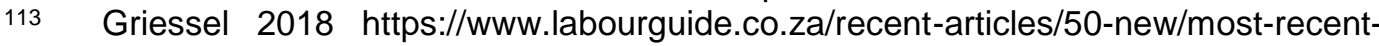
publications/2547-using-emoji-s-when-the-smiley-becomes-serious.

114 Gus Ghanam v John Does No 312201, Macomb Circuit Court, LC No 2012-001739CZ.

115 South African Human Rights Commission obo South African Jewish Board of Deputies v Masuku 2017 ZAEQC 1 (29 June 2017) para 54.

$116 \quad H \vee W$ para 28.

117 ELRC 2018 http://www.elrc.org.za/awards/case-no-elrc97-1617gp paras 41, 65.
} 
for sexual harassment in the Code of Good Practice on the Handling of Sexual Harassment Cases in the Workplace includes "the sending by electronic means or otherwise of sexually explicit text". ${ }^{118}$

In Dagane $v S S S B C^{119}$ the applicant argued that he did not make the posts concerned and that either somebody else had accessed his account and made the racist posts or had created another account using his details and photos. The commissioner concluded that the applicant's argument was far-fetched and found the supporting evidence in the fact that the applicant had restricted access to his Facebook page, had not given his password to anybody and, after he had closed his Facebook account, no account in his name had existed. The commissioner further stated that if somebody else had made the posts, the applicant would have distanced himself from having made the remarks, but he had not.

Swales ${ }^{120}$ and Fourie ${ }^{121}$ contend that social media evidence can be either documentary hearsay evidence or real evidence (automated or mechanically created with no human intervention). The purpose of presenting the evidence will determine whether the evidence is documentary or real. Where a document is presented as evidence that the document exists or was sent to a specific person it will constitute real and not documentary evidence and will not be treated as hearsay evidence. ${ }^{122}$ In Dagane $v S S S B C$, the case of a former policeman who posted racist comments on the Facebook page of Mr Julius Malema, Steenkamp J held that Facebook postings are hearsay evidence which is inadmissible but that, like all hearsay evidence, they may be found admissible in terms of section 3(c) of the Law of Evidence Amendment Act 16 of $1988 .{ }^{123}$

Frieden and Murray considered the American Federal Rules of Evidence and concluded that chatroom transcripts can be authenticated by evidence that the alleged sender had access to the computer, was active in the chat room when the relevant chats were posted, had created the screen name under which the chats were posted, and had admitted to having conducted

\footnotetext{
118 ELRC 2018 http://www.elrc.org.za/awards/case-no-elrc97-1617gp para 61.

119 Dagane v SSSBC 2018 ZALCJHB 114 (16 March 2018) paras 32, 36, 38 (Dagane v SSSBC).

120 Swales 2018 PELJ http://dx.doi.org/1 0.17159/1727-3781/2018/v21 i0a4496 15-16.

121 Fourie Using Social Media as Evidence 8.

122 Fourie Using Social Media as Evidence 13.

123 Dagane $v$ SSSBC paras 30-31.
} 
similar chats. They further held that it is essential to ensure the transcripts accurately reflect the communication. ${ }^{124}$

Nel ${ }^{125}$ suggests that when a user receives a complaint about an offending post, he or she should remove the post and offer a prompt, unreserved apology in the same medium and with the same prominence as the original post. However, Douglas ${ }^{126}$ asserts that removing a post does not guarantee that no future damage may result from the post because the internet allows almost endless replication. Somebody else could have already copied, forwarded or shared a post before it was removed. He states: "the potential for a defamatory accusation to re-emerge in the future - a potential that can be realised by the operation of the grapevine effect - justifies an award of damages to vindicate the plaintiff's reputation". ${ }^{127}$

\subsection{Educators' right to privacy and obtaining digital footprint evidence}

The test to determine whether there is a legitimate expectation of privacy, as set out in Bernstein $v$ Bester, ${ }^{128}$ consists of two questions, namely whether the person has a subjective right to privacy and whether society has recognised such an expectation as objectively reasonable. Judge Ackerman held that to determine "whether the individual has lost his/her legitimate expectation of privacy, the court will consider such factors as whether the item was exposed to the public, abandoned, or obtained by consent". An individual's subjective expectation of privacy is shaped by his or her conduct. ${ }^{129}$ Burkell et a/ ${ }^{130}$ refer to the Canadian Charter of Rights and Freedoms and case law in concluding that courts will consider the following factors when determining the degree of expectation of privacy that a specific person can have with regard to his or her social media sites:

a) "The social (and therefore public) nature of Facebook and other networking sites". Burkell et a/ ${ }^{131}$ contend that "by choosing to act in a space to which others have ready access, one surrenders one's claim to privacy with respect to a potential audience." In Smith $v$ Partners in Sexual Health, Commissioner Bennet emphasised that one does not

\footnotetext{
124 Frieden and Murray 2011 Rich $J$ L \& Tech 20-21.

125 Nel 1997 CILSA 172.

126 Douglas 2015 MALR 374.

127 Douglas 2015_MALR 378.

128 Bernstein v Bester 1996 ZACC 2 (27 March 1996) para 75.

129 Ghoshray 2013 N Ky L Rev 617, 623.

130 Burkell et al 2014 Inf Commun Soc 976.

131 Burkell et al 2014 Inf Commun Soc 976.
} 
have a reasonable expectation of privacy with regard to internet-based social networking sites because the site structure allows the viewing (the interception) of conversations by persons not party to those communications. ${ }^{132}$

b) "The number of Facebook friends a user has". In Pritchard v. Van Nes ${ }^{133}$ the facts that the defendant had more than 2000 Facebook friends and no privacy settings were taken to indicate that the widespread dissemination of the defamatory postings was imminent.

c) "The extent to which the user has limited access to her [sic] profile through her privacy setting". This is referred to as a person's "visibility" - that is, "the extent to which the user's profile can be accessed by other users or even by persons using search engines such as Google". ${ }^{134}$ From the CCMA cases Sedick $v$ Krisray and Fredericks $v$ Jo Barkett Fashions it is evident that if one does not exercise options to restrict access to one's Facebook page by changing the settings to private and not choosing the automatic sign-in option, one in effect stays within the public domain.

Another way to restrict access is by choosing who may have access. Roos ${ }^{135}$ argues that one will have a greater expectation of privacy where one reveals information to one's friends only. As was indicated in US v Mereglido, ${ }^{136}$ "using more secure privacy settings reflects the user's intent to preserve information as private". Though this will not ensure total privacy, it does allow a greater expectation of privacy. It also allows one to claim protection in terms of section 4(1) of the Regulation of Interception of Communication and Provision of Communication-related Information Act 70 of 2002 if the employer or person who obtained the evidence is not a "party to the communication" that he or she has intercepted.

When one posts a non-work related post on business social media sites, one has no expectation of privacy. An employee of Chrysler was dismissed after he mistakenly posted a tweet that included a swear word on the business's twitter account instead of on his own account. ${ }^{137}$ An expectation of privacy in the truly personal realm will be more likely to be regarded as

132 Smith v Partners in Sexual Health (Non-profit) 201132 ILJ 1470 (CCMA) para 51. Also see US $v$ Mereglido para 526.

Pritchard $v$ Van Nes para 83.

Roos and Slabbert 2014 PELJ http://dx.doi.org/10.4314/pelj.v17i6.18 2817.

Roos 2012 SALJ 401.

US v Mereglido para 525.

Karlen 2014 Allied Academies International Internet Conference 55. 
being reasonable than expectations of privacy within communal relations and activities. ${ }^{138}$ Thus, when one moves into the realm of business and social interaction, the scope of one's personal space shrinks, and this decreases but does not obliterate one's expectation of privacy. ${ }^{139}$ Judge Sachs, in Mistry v Interim National Medical and Dental Council, ${ }^{140}$ indicated that the following factors should be considered in determining the invasion of the right to information privacy:

a) whether the information was obtained in an intrusive manner;

b) whether it was about intimate aspects of the applicant's personal life (thus how great was the expectation of privacy with regard to the information);

c) whether it involved data provided by the applicant for one purpose but which was used for a different purpose;

d) whether the information was disseminated to the press or the general public or persons from whom the applicant could reasonably expect such private information would be withheld.

Equally, these factors apply in instances where an employer has accessed an employee's social media sites without permission. It is also a criminal offence to intentionally access or intercept data without authority or permission. ${ }^{141}$ Note, however, that Plasket $\mathrm{J}$ held in Harvey $v$ Niland ${ }^{142}$ that the fact that this is a criminal offence does not mean that the evidence obtained in this manner is inadmissible. This Act is silent on whether evidence obtained in contravention of this section is inadmissible. Thus, in civil cases such as defamation cases, the fact that the employer has obtained evidence in an unlawful manner from one's social media site may not automatically make such evidence inadmissible. Fourie ${ }^{143}$ contends that social media evidence will still be subject to the rules of relevance and authenticity, as well as the other exclusionary rules of evidence, before it may be admitted. He further argues that printouts or transcripts of social media evidence will be the best form in which to present the evidence. If

\footnotetext{
138 Currie and De Waal Bill of Rights Handbook 298.

139 Protea Technology Ltd $v$ Wainer 19979 BCLR 1225 (W) paras 496C-D.

140 Mistry $v$ Interim National Medical and Dental Council 1998 ZACC 10 (29 May 1998) paras 51-52. Factors summarised by Currie and De Waal Bill of Rights Handbook 303.

141 Section 86(1) of the Electronic Communications and Transactions Act 25 of 2002.

142 Harvey $v$ Niland 2015 ZAECGHC 149 (3 December 2015) paras 38, 43.

143 Fourie Using Social Media as Evidence 85, 88.
} 
properly authenticated, there is no need for insisting on the "original" social media evidence. ${ }^{144}$

The Electronic Communications and Transactions Act ${ }^{145}$ defines "data message" as "data generated, sent, received or stored by electronic means" which can include electronic information generated via social media. ${ }^{146}$ The Act stipulates that the following aspects must be considered when assessing the evidential weight of a data message:

(a) the reliability of the manner in which the data message was generated, stored or communicated;

(b) the reliability of the manner in which the integrity of the data message was maintained;

(c) the manner in which its originator was identified.

\section{Conclusion}

Not considering the unique characteristics of social media can be hazardous to educators' employment, especially in the light of accepted legal principles regulating the employment relationship. The unique nature of social media will inter alia affect users' control over their audiences, their expectations of privacy and the way they exercise their right to freedom of expression.

Several considerations with regard to employment relations impact on social media misconduct. Social media posts that blemish the reputation of the state, employer or school; that bring the profession into disrepute; that affect the trust relationship; that may result in the state's or the employer's being held vicariously liable (either in terms of common law or statutory provisions) and which may result in the legitimate interests of the state, employer or school being negatively affected, can draw dismissal. The consequences for educators of their inappropriate use of social media are complex, because they are held to a high moral and professionalism standard. This high standard is grounded in the fact that educators work with children and have to act as role models to them. Educators' unique professionalism and the statutory state liability supports a "stricter" response to social media misconduct than would be the case for employees in general.

Though existing law and policy cover social media misconduct and social media-related unprofessional conduct sufficiently, the misuse of social

\footnotetext{
144 Fourie Using Social Media as Evidence 86-87.

145 Section 1 of the Electronic Communications and Transactions Act 25 of 2002.

146 Watney 2009 http://go.warwick.ac.uk/jilt/2009_1/watney 2.
} 
media creates unique dangers. For example, educators may think that what they post will be viewed by only those to whom they have granted viewing rights. However, employers can gain access to such posts through the accounts of others whom the educator has befriended. They may befriend a colleague with whom they would not have had any social relationship in real life, but because of the social media friendship they will develop a false sense of camaraderie and familiarity in relation to the colleague. They can develop a false sense of control, attachment and empowerment and think that they can use social media to rally support from "like-minded" people, but in the process they can injure the reputation of their employer, school or profession. The social media allow for multiple creators of a communication, and the owner of the social media account can be held liable for any offending posts made by others on his or her site. Liability attaches not only to the original publication, but also to re-publication and to responses to the publication. Furthermore, due to the unique nature of social media, the damage that may result from an offending post has the prospect of increasing in severity over time.

As professionals, educators should keep in mind that

- $\quad$ they are held to a high standard of professionalism because they work with and have to be role models to children. Online personae have a definite impact on educators' professional image, the profession and also the reputation and image of the employer (department) and the school;

- $\quad$ social media sites are public spaces, and whether access to a social media account is restricted or not impacts on the level of the legitimate expectation of privacy a user has. Not protecting an account by means of a password, allowing friends-of-friends access and having a high number of friends limit the legitimate expectation of privacy. There is no legitimate expectation of privacy with regard to some social media sites, such as Twitter. Using privacy settings has two benefits: it protects privacy better and, should a comment be posted that someone else regards as inappropriate, the court will regard the harm as less serious than it would have, had privacy settings not been in place;

- it is essential to regularly access one's own social media accounts and to monitor the posts that others make on one's sites. Should a third party make a post or posts that might constitute hate speech or harassment, or that is pornographic or defamatory in nature, one 
should remove it and distance oneself from the post or posts concerned. Even in cases where this does not prevent the site owner from being charged, such removal may be considered a mitigating factor;

- $\quad$ irrespective of where one uses one's work computer, the employer's policy will regulate how and for what it may be used.

\section{Bibliography}

\section{Literature}

Akiti 2012 Val U L Rev

Akiti L "Facebook off Limits? Protecting Teachers' Private Speech on Social Networking Sites" 2012 Val U L Rev 119-167

Bagley, Hargraves and DiGiacinto 2014 Radiologic Technology Bagley JE, Hargraves K and DiGiacinto DD "Imagining Professionals' Views of Social Media and its Implications" 2012 Radiologic Technology 377-389

Beckmann and Füssel 2013 De Jure

Beckmann $\mathrm{J}$ and Füssel $\mathrm{H}$ "The Labour Rights of Educators in South Africa and Germany and Quality Education: An Exploratory Comparison" 2013 De Jure 557-582

Boyd and Ellison 2008 JCMC

Boyd DM and Ellison NB "Social Network Sites: Definition, History and Scholarship" 2008 JCMC 210-230

Burkell et al 2014 Inf Commun Soc

Burkell J et al "Facebook: Public Space or Private Space? " 2014 Inf Commun Soc 974-985

Cain 2008 Am J Pharm Educ

Cain $\mathrm{J}$ "Online Social Networking Issues within Academia and Pharmacy Education" 2008 Am J Pharm Educ 1-7

Coetzee 2011 CARSA

Coetzee SA "Forms of Educator-on-learner Sexual Misconduct Redefined" 2011 CARSA 51-64

Coetzee 2018 CARSA

Coetzee SA "Holding the State Directly Liable for Educator-on-learner Sexual Abuse" 2018 CARSA 30-44 
Currie and De Waal Bill of Rights Handbook

Currie I and De Waal J The Bill of Rights Handbook $6^{\text {th }}$ ed (Juta Lansdowne 2013)

DeNardis "Social Media Challenge to Internet Governance"

DeNardis L "The Social Media Challenge to Internet Governance" in Graham M and Dutton WH (eds) Society and the Internet: How Networks of Information and Communication are Changing our Lives (Oxford University Press Oxford 2014) 349-359

Douglas 2015 MALR

Douglas M "'Their Evil Lies in the Grapevine Effect': Assessment of Damages in Defamation by Social Media" 2015 MALR 367-379

Fourie Using Social Media as Evidence

Fourie PF Using Social Media as Evidence in South African Courts (LLM-dissertation North-West University 2016)

Frieden and Murray 2011 Rich $J$ L \& Tech

Frieden JD and Murray LM 2011 "The Admissibility of Electronic Evidence under the Federal Rules of Evidence" 2011 Rich $J$ L \& Tech 1-39

Gondwe Protection of Privacy in the Workplace

Gondwe M The Protection of Privacy in the Workplace: A Comparative Study (LLD-thesis University of Stellenbosch 2011)

Ghoshray 2013 N Ky L Rev

Ghoshray S "Employer Surveillance versus Employee Privacy: The New Reality of Social Media and Workplace Privacy" 2013 N Ky L Rev 593-626

Grimmelmann 2008-2009 lowa L Rev

Grimmelmann J "Saving Facebook" 2008-2009 lowa L Rev1137-1206

Homann Legal Implications of Defamatory Statements

Homann LH The Legal Implications of Defamatory Statements on Social Media Platforms in South Africa (LLM-dissertation North-West University 2015)

Jolly, Ellison and Wong 2014 Governance Directions

Jolly G, Ellison M and Wong S "Social Media and Employment Law" 2014 Governance Directions 169-171 
Karlen 2014 Allied Academies International Internet Conference

Karlen JM "Social Media and the Employment Relationship" 2014 Allied Academies International Internet Conference 54-59

Kimmons and Veletsianos 2015 Learn Media Technol

Kimmons R and Veletsianos G "Teacher Professionalization in the Age of Social Networking Sites" 2015 Learn Media Technol 480-501

Lam 2016 Employee Relations

Lam H "Social Media Dilemmas in the Employment Context" 2016 Employee Relations 420-437

Maharaj 2015 De Rebus

Maharaj S "Keep your Tweets Twibel Free" 2015 De Rebus 28-30

Mangan "Social Media in the Workplace"

Mangan D "Social Media in the Workplace" in Mangan D and Gillies L (eds) The Legal Challenges of Social Media (Edward Elgar Cheltenham 2017) 201-221

McGregor 2004 SA Merc LJ

McGregor M "The Right to Privacy in the Workplace: General Case Law and Guidelines for Using the Internet and E-mail" 2004 SA Merc LJ 638-650

Miller 2013 FDCC Quarterly

Miller MB "Avatars and Social Media: Employment Law Risks and Challenges in the Virtual World" 2013 FDCC Quarterly 279-294

Neethling 2014 LitNet Akademies

Neethling $\mathrm{J}$ "Vonnisbespreking: Facebook en Persoonlikheidsbeskerming" 2014 LitNet Akademies 40-51

Neethling and Potgieter Law of Delict

Neethling $\mathrm{J}$ and Potgieter JM Neethling - Potgieter - Visser Law of Delict $7^{\text {th }}$ ed (LexisNexis Durban 2015)

Neethling, Potgieter and Visser Neethling's Law of Personality Neethling J, Potgieter JM and Visser PJ Neethling's Law of Personality $2^{\text {nd }}$ ed (LexisNexis Butterworths Durban 2005)

Nel 1997 CILSA

Nel S "Defamation on the Internet and Other Computer Networks" 1997 CILSA 154-174. 
Page 2013 British Education Research Journal

Page D "Teacher Misbehaviour: An Analysis of Disciplinary Orders by the General Teaching Council for England" 2013 British Education Research Journal 545-564

Roos 2012 SALJ

Roos A "Privacy in the Facebook Era: A South African Legal Perspective" 2012 SALJ 375-402

Spinelli 2010 Elon Journal of Undergraduate Research in Communication Spinelli CF "Social Media: No 'friend' of Personal Privacy" 2010 Elon Journal of Undergraduate Research in Communication 59-69

Subramanien and Whitear-Nel 2013 SAJLR

Subramanien D and Whitear-Nel N "A Fresh Perspective on South African Law Relating to the Risks Posed to Employers when Employees Abuse the Internet" 2013 SAJLR 9-23

Thornthwaite 2016 Asia Pac J Hum Resour

Thornthwaite L "Chilling Times: Social Media Policies, Labour Law and Employment Relations" 2016 Asia Pac J Hum Resour 332-351

\section{Case law}

Beautiful You Health and Beauty Clinic (Pty) Ltd v Moolman 2015 ZAECPEHC 13 (10 March 2015)

Bernstein v Bester 1996 ZACC 2 (27 March 1996)

Bland v Roberts 730 F3d 368 4th Cir 2013

Chatfield v Deputy Head (Correctional Service Canada) 2017 PSLREB 2

Dagane v SSSBC 2018 ZALCJHB 114 (16 March 2018)

Dutch Reformed Church Vergesig v Rayan Sooknunan 20126 SA 201 (GSJ)

EC for Education and Culture, Free State v Louw 2005 ZASCA 85 (23 September 2005)

F v Minister of Safety and Security 2011 ZACC 37 (15 December 2011)

Flocutt (Pty) Ltd v Eisenberg 2016 ZAFSHC 200 (20 October 2016) 
Fredericks / Jo Barkett Fashions 2011 JOL 27923 (CCMA)

Griffiths v Rose 2011 FCA 30

Gus Ghanam v John Does No 312201, Macomb Circuit Court, LC No 2012001739-CZ

H v W 2013 ZAGPJHC 1 (30 January 2013)

Hanniker / One and Only Cape Town (Pty) Ltd 201711 BALR 1191 (CCMA) Harvey v Niland 2015 ZAECGHC 149 (3 December 2015)

Isparta v Richter 2013 ZAGPPHC 243 (4 September 2013)

$K v$ Minister of Safety and Security 2005 ZACC 8 (13 June 2005)

KS v AM 2017 ZAGPJHC 297 (24 October 2017)

Khumalo v Holomisa 2002 ZACC 12 (14 June 2002)

Knupffer v London Express Newspapers 1944 UKHL 1

Land v L'Anse Creuse Public School Board of Education 789 NW2d 458 2010

Masemola v Commission for Conciliation, Mediation and Arbitration 2016 ZALCJHB 183 (17 May 2016)

Media 24 v SA Taxi Securitisation 2011 ZASCA 117 (5 July 2011)

Media Workers Association of SA obo Mvemve and Kathorus Community Radio 201031 ILJ 2217 (CCMA)

MH v Rhodes University (20 March 2017) 20177 BALR 785 (CCMA)

Mistry v Interim National Medical and Dental Council 1998 ZACC 10 (29 May 1998)

Munroe v Central Bucks School District 090415 FED3, 14-3509 2015

National Union of Food, Beverage, Wine, Spirits and Allied Workers Union obo Arendse / Consumer Brands Business Worcester, a Division of Pioneer Foods (Pty) Ltd 20147 BALR 716 (CCMA)

NDPP v Mahomed 2007 ZASCA 135 (8 November 2007) 
Pehlani v Minister of Police 2014 ZAWCHC 146 (25 September 2014)

Pritchard v Van Nes 2016 BCSC 686

Protea Technology Ltd v Wainer 19979 BCLR 1225 (W)

Sedick v Krisray (Pty) Ltd 20118 BALR 879 (CCMA)

Smith v Partners in Sexual Health (Non-profit) 201132 ILJ 1470 (CCMA)

South Africa Associated Newspapers Ltd v Estate Pelser 19754 SA 797 (A)

South African Human Rights Commission obo South African Jewish Board of Deputies v Masuku 2017 ZAEQC 1 (29 June 2017)

Spanierman v Hughes 576 F Supp 2d 2922008

State of Wisconsin v Ebersold 2007 WI APP 232

Toker Bros (Pty) Ltd and Keyser 200526 ILJ 1366 (CCMA)

US v Mereglido 2012 WL 3264501 SDNY Aug 10, 2012

\section{Legislation}

Constitution of the Republic of South Africa, 1996

Electronic Communications and Transactions Act 25 of 2002

Employment of Educators Act 76 of 1998

Labour Relations Act 66 of 1995

Law of Evidence Amendment Act 16 of 1988

Protection of Personal Information Act 4 of 2013

Regulation of Interception of Communication and Provision of Communication-related Information Act 70 of 2002

South African Council for Educators Act 31 of 2000

South African Schools Act 84 of 1996 


\section{Internet sources}

Alfreds $2015 \mathrm{https}: / / \mathrm{www}$.fin24.com/Tech/News/Privacy-is-dead-on-socialmedia-legal-expert-20151016

Alfreds D 2015 "Privacy is Dead on Social Media - Legal Expert" Fin24 (16 October 2015) https://www.fin24.com/Tech/News/Privacy-is-dead-onsocial-media-legal-expert-20151016 accessed 30 October 2018

Amedie $2015 \mathrm{http}: / /$ scholarcommons.scu.edu/engl_176/2

Amedie J 2015 The Impact of Social Media on Society http://scholarcommons.scu.edu/engl_176/2 accessed 3 November 2018

Beaver et al 2013 https://www.americanbar.org/content/dam/aba/ administrative/litigation/materials/aba-annual-2013/written_materials/15_ 1_social_media_evidence.authcheckdam.pdf Beaver GL et al 2013 Social Media Evidence: How to Find It and How to Use It https://www.americanbar.org/content/dam/aba/administrative /litigation/materials/aba-annual-2013/written_materials/15_1_social_media _evidence.authcheckdam.pdf accessed 30 October 2018

Davey 2015 http://www.golegal.co.za/social-media-in-the-workplace/ Davey R 2015 "Social media in the workplace" GoLegal Industry News and Insights (13 November 2015) http://www.golegal.co.za/social-media-in-theworkplace/ accessed 3 November 2018

Davey 2016 https://www.golegal.co.za/off-duty-misconduct-in-the-age-ofsocial-media/

Davey R 2016 "Off duty misconduct in the age of social media" GoLegal Industry News and Insights (15 February 2016) https://www.golegal.co.za/off-duty-misconduct-in-the-age-of-social-media/ accessed 3 November 2018

Du Toit 2018 https://labourguide.co.za/most-recent/1358-social-mediaguidelines-on-the-policy-for-employees-using-social-media-for-nonbusiness-purposes

Du Toit J 2018 Social Media: Guidelines on the Policy for Employers Using Social Media for Non-business Purposes https://labourguide.co.za/mostrecent/1358-social-media-guidelines-on-the-policy-for-employees-usingsocial-media-for-non-business-purposes accessed 3 November 2018

ELRC 2018 http://www.elrc.org.za/awards/case-no-elrc97-1617gp Education Labour Relations Council 2018 Arbitration Award ELRC9716/17GP: NAPTOSA obo Makhaphela Khayalethu Stephen / South West 
Gauteng TVET College and Department of Higher Education and Training http://www.elrc.org.za/awards/case-no-elrc97-1617gp accessed 30 October 2018

ELRC 2018 http://www.elrc.org.za/awards/case-no-pses434-1617-kzn-0 Education Labour Relations Council 2018 Arbitration Award PSES43416/17 KZN: Zungu / Department of Education - KwaZulu-Natal http://www.elrc.org.za/awards/case-no-pses434-1617-kzn-0 accessed 3 November 2018

Facebook 2018 https://www.facebook.com/principles.php Facebook 2018 Facebook Principles https://www.facebook.com /principles.php accessed 4 November 2018

Griessel 2018 https://www.labourguide.co.za/recent-articles/50-new/mostrecent-publications/2547-using-emoji-s-when-the-smiley-becomes-serious Griessel J 2018 Using Emoji's - When the Smiley Becomes Serious https://www.labourguide.co.za/recent-articles/50-new/most-recentpublications/2547-using-emoji-s-when-the-smiley-becomes-serious accessed 10 November 2018

Merriam-Webster.com date unknown https://www.merriamwebster.com/dictionary/social\%20media

Merriam-Webster.com date unknown Social Media https://www.merriamwebster.com/dictionary/social\%20media accessed 3 November 2018

Millard and Bascerano 2016 PELJ http://dx.doi.org/10.17159/17273781/2016/v19i0a555

Millard D and Bascerano EG "Employers' Statutory Vicarious Liability in terms of the Protection of Personal Information Act" 2016 PELJ http://dx.doi.org/10.17159/1727-3781/2016/v19i0a555 (accessed 30 October 2018)

National School Public Relations Association date unknown https://www.nspra.org/cap

National School Public Relations Association date unknown School Public Relations: The Essential Ingredient to Student and School Success https://www.nspra.org/cap 3 November 2018

Njilo and Chambers 2018 https://www.timeslive.co.za/news/southafrica/2018-08-15-lecturer-in-facebook-row-faces-urgent-suspension-uctinsists/ 
Njilo N and Chambers D 2018 "Lecturer in Facebook Row Faces Urgent Suspension, UCT insists" Times Live South Africa (15 August 2018) https://www.timeslive.co.za/news/south-africa/2018-08-15-lecturer-infacebook-row-faces-urgent-suspension-uct-insists/ accessed 3 November 2018

Roos and Slabbert 2014 PELJ http://dx.doi.org/10.4314/pelj.v17i6.18 Roos A and Slabbert M 2014 "Defamation on Facebook: Isparta $v$ Richter 20136 SA 529 (GP)" PELJ 2844-2868 http://dx.doi.org/10.4314/ pelj.v17i6.18 accessed 6 November 2018

SACE 2001 https://www.sace.org.za/assets/documents/uploads/sace 24644-2017-02-08-Code\%20of\%20ethics\%20Brochure\%20FINAL\%20 PRINT\%205\%20SEPT.pdf

South African Council for Educators 2001 Code of Professional Ethics https://www.sace.org.za/assets/documents/uploads/sace_24644-2017-0208-Code\%20of\%20ethics\%20Brochure\%20FINAL\%20PRINT\%205\% 20SEPT.pdf accessed 3 November 2018

Shange 2016 http://www.news24.com/SouthAfrica/News/yes-your-bosscan-fire-you-for-social-media-posts-attorney-20160202 Shange N 2016 "Yes, your Boss can Fire you for Social Media Posts Attorney" News24 (2 $\quad$ February 2016) http://www.news24.com/SouthAfrica/News/yes-your-boss-can-fire-you-forsocial-media-posts-attorney-20160202 accessed 3 November 2018

Swales 2018 PELJhttp://dx.doi.org/1 0.17159/1727-3781/2018/v21i0a4496 Swales L 2018 "An Analysis of the Regulatory Environment Governing Hearsay Electronic Evidence in South Africa: Suggestions for Reform - Part Two" $2018 \quad P E L J \quad 1-34 \quad$ http://dx.doi.org/1 $\quad$ 0.17159/17273781/2018/v21i0a4496 accessed 7 November 2018

Thomas 2018 https://www.thenational.ae/opinion/comment/there-sstrength-of-hate-in-numbers-on-social-media-1.763908

Thomas J 2018 "There's Strength of Hate in Numbers on Social Media" The National (26 August 2018) https://www.thenational.ae/opinion/comment/ there-s-strength-of-hate-in-numbers-on-social-media-1.763908 accessed 3 November 2018

Van Vuuren 2015 https://www.werksmans.com/wp-content/ uploads/2015/11/044191-WERKSMANS-legal-nov-legal-impacts.pdf Van Vuuren N 2015 "The Legal Impact of Social Media Networks International Trends" Legal Brief (November 2015) 
https://www.werksmans.com/wp-content/uploads/2015/11/044191-

WERKSMANS-legal-nov-legal-impacts.pdf accessed on 29 October 2018

Watney 2009 http://go.warwick.ac.uk/jilt/2009_1/watney

Watney M 2009 "Admissibility of Electronic Evidence in Criminal Proceedings: An Outline of the South African Legal Position" 2009 JILT http://go.warwick.ac.uk/jilt/2009_1/watney accessed 12 October 2018

\section{List of Abbreviations}

Am J Pharm Educ

Asia Pac J Hum Resour

CARSA

CCMA

CILSA

ELRC

FDCC

GTC

Inf Commun Soc

lowa L Rev

JCMC

JILT

Learn Media Technol

MALR

N Ky L Rev

NDDP

PELJ

Rich J L \& Tech

SA Merc LJ

SACE

SAJLR

SALJ

Val U L Rev
American Journal of Pharmaceutical Education

Asia Pacific Journal of Human Resources

Child Abuse Research South Africa

Commission of Conciliation, Mediation and Arbitration

Comparative and International Law Journal of Southern Africa

Education Labour Relations Council

Federation of Defense and Corporate

Counsel

General Teaching Council

Information, Communication and Society

lowa Law Review

Journal of Computer-mediated

Communication

Journal of Information, Law \& Technology

Learning, Media and Technology

Media and Arts Law Review

Northern Kentucky Law Review

National Director of Public Prosecutions

Potchefstroom Electronic Law Journal

Richmond Journal of Law and Technology

South African Mercantile Law Journal

South African Council for Educators

South African Journal of Labour Relations

South African Law Journal

Valparaiso University Law Review 